\title{
Effects of Garlic Powder (Allium Sativum) Supplementation on Carcass Characteristics of West African Dwarf Rams
}

\author{
Alamuoye Oluwatoyin Folake ${ }^{1, *}$ and Adegun Maria Kikelomo ${ }^{2}$ \\ ${ }^{1,2}$ Department of Animal Science, Ekiti State University \\ Ado- Ekiti, Nigeria \\ *Corresponding author's email: oluwatoyin.alamuoye [AT] yahoo.com
}

\begin{abstract}
The effect of garlic powder (Allium sativum) supplementation on quantitative carcass and noncarcass characteristics of West African Dwarf Rams was investigated. A total of 40 West African Dwarf yearling rams were randomly assigned to five dietary groups in a completely randomized design. Each group contained eight rams (two rams of four replicates) assigned separately to five dietary treatments having garlic powder as supplements at $0 \%$ (control, diet 1), $0.2 \%$ (diet 2), $0.4 \%$ (diet 3), $0.6 \%$ (diet 4) and $0.8 \%$ (diet 5) respectively. Rams in each replicate were housed in individual pen and fed with Panicum maximum at $0.2 \mathrm{~kg} / \mathrm{ram} / \mathrm{day}$ as basal diets and water was provided ad libitum, for a period of 12 weeks. The result showed that the dressing percentage varied among treatment groups with the highest value (55.76 $\pm 1.82 \%)$ obtained from rams fed $4 \%$ garlic powder inclusion (treatment 3). The carcass characteristics significantly varied $(p<0.05)$ among treatments. Also, dietary treatments had no significant $(p>0.05)$ effect on the composition of the non-carcass components. Meat to bone ratio was significantly $(p<0.05)$ higher in the flank cut of treatment 5 than cut-parts of other treatments. The study concluded that garlic powder (Allium sativum) supplementation increased carcass yield of West African Dwarf ram.
\end{abstract}

Keywords--- Carcass, garlic, supplementation, West African Dwarf rams

\section{INTRODUCTION}

Sheep production is one of the major sectors of livestock farming that provides animal protein to the teeming population in a developing world such as Nigeria. The West African Dwarf (WAD) sheep, predominantly found in southwestern Nigeria have high fecundity, hardy, trypano-tolerant but reach market weight longer than other breeds of sheep in Nigeria $[1,2]$. Quite a number of researches have aimed at improving the productivity of WAD sheep $[3,4,5,6]$. Most of these researches have focused on the use of alternative feed ingredients aimed at reducing cost of production of the animals. Consumer's demand and butcher's expectation for good quantity and quality meat can also be achieved by improving carcass characteristics and meat quality traits through other strategies.

Feeding strategy is mostly used as a quality control tool in animal performance [7]. Also, diets dominantly affect the quality of carcasses and meat with more than 30\% [8]. Hormones and antimicrobial agents as growth promoters are added to diets of animals to increase growth rates, improve feed efficiency and product quality [9]. Many of these substances are adjudged risky due to possible future drug resistance of humans as an aftermath of exposure to their minute doses in animal products. The ban on synthetic antibiotics and growth promoters especially in the developed world has necessitated the need for animal nutritionists to search for alternatives that would be effective for improved nutrient utilization and carcass yield. Phytochemicals in animal feeds have been proposed as replacement for synthetic growth promoters and they may have positive effects on the meat production chain [10]. Garlic is a phytogenic plant with active components having positive effects and conveying antimicrobial, hypocholesterolemic, antioxidant and growth enhancing properties on animals. It has been adjudged as a rich source of essential organic nutrients with high antioxidant properties that improve growth, production performance and health of livestock [11]. Its action results in improved gut activity, immunity and improved health status of the animals [12].

Many of the studies on the effect of phytochemicals on carcass and meat quality of chickens and pigs have yielded positive results, but their effects on ruminants have been inconclusive $[13,10]$. It is imperative to propose more in-vivo studies to ascertain the effect of phytochemical inclusion in sheep diet. The aim of this study is to investigate the effect of garlic powder supplementation on carcass and non-carcass yield of West African Dwarf rams. 


\subsection{Experimental Site}

\section{MATERIALS AND METHODS}

The study was conducted at the small ruminant unit of the Faculty of Agricultural Sciences' Teaching and Research Farm, Ekiti State University, Ado-Ekiti, Nigeria. It is a tropical climate with a temperature range of $20^{\circ} \mathrm{C}$ and $28^{\circ} \mathrm{C}$ and a bimodal rainfall distribution between March and November and a peak in June and September. The average precipitation in the area is $1367 \mathrm{~mm}$. Ado Ekiti experiences a warm sub humid tropical climate with a mean rainfall of about 112 days.

\subsection{Animals and Management}

A total of 40 intact yearlings West African Dwarf rams weighing an average initial weight of $12.4 \mathrm{~kg}$ were reared at the Ruminant unit of the Teaching and Research Farm of Ekiti State University, Ado-Ekiti. A standard composition diet (Table 1) was formulated in which five dietary treatments were constituted at garlic inclusion level at $0 \%$ (basal diet), and $0.2 \%, 0.4 \%, 0.6 \%$ and $0.8 \%$. The animals were randomly assigned to five treatments and each treatment has four replicates of two rams per replicate, in a completely randomized design (CRD). The feeding trial lasted for the period of twelve weeks. The WAD rams were fed with guinea grass (Panicum maximum) as basal diets.

Table 1. Composition of experimental diets

\begin{tabular}{ll}
\hline Items & Composition \\
\hline Ingredients & \\
Soybean meal & 10.0 \\
Maize & 35.0 \\
Rice bran & 15.0 \\
Brewer's dry grain & 37.5 \\
Bone meal & 1.0 \\
Salt & 1.0 \\
Vitamin/mineral & 0.25 \\
Premix & 0.25 \\
Total & 100 \\
Calculated protein $(\%)$ & 16.07 \\
Calculated Energy $(\mathrm{kcal} / \mathrm{kg})$ & 2605.7 \\
\hline
\end{tabular}

\subsection{Slaughtering, Evisceration and Washing of carcasses}

Three rams were randomly selected from each treatment group on the last day of the feeding trial, after which feed had been withdrawn from the animals for 18 hours and only water provided. The animals were weighed to determine average live weight and mechanically immobilized and slaughtered. Animal bodies were skinned and the head and feet were removed. Carcasses were cut open, with internal organs removed and washed. Hot carcass weight was taken before chilling at the temperature of $4^{\circ} \mathrm{C}$. All internal (inert) organs were excised and weighed separately and expressed as the percentage of live weight. The head, tail, leg and neck were separated, weighed and expressed as percentage of live weight. Dressing percentage was determined using the formula:

Dressing percentage $=$ Eviscerated weight $\quad X 100$

Live weight

\subsection{Carcass dissection}

The head of the animals was removed at the atlanto-occipital joint. Fore and hind feet were removed at the carpalmetacarpal and tarsal-metatarsal joints respectively [14]. Warm carcass was halved separately by splitting into left and right along the vertebral axis by the use of a meat saw. Halved carcass was weighed and expressed as percentage of dressed carcass. The right halved hot carcass was dissected into standard cuts (shoulder, rib, loin, flank and round) at the reference points. Shoulder was dissected as a cut between $5^{\text {th }}$ and $6^{\text {th }}$ ribs, rib was dissected between $12^{\text {th }}$ and $13^{\text {th }}$ rib, loin was separated from the rib, and round was separated just in front of the hip bones by cutting through the back where the curve of the leg muscles blends into the loin. Weight of the primal cuts was determined as hot cut-parts and chilled at temperature of $4^{\circ} \mathrm{C}$ for 24 hours. Thawed left halved carcass was dissected into primal cuts and weighed separately. The raw cut-parts were dissected into meat (lean), fat and bone portions. The percentage of dissected cut-parts was determined relative to the weight of carcass cut-parts. The ratio of meat to bone of dissected of each primal cuts was evaluated while the proportion of meat, bone and fat of each cuts were determined relative to raw weight of primal cut.

$\%$ dissected cut $($ meat $/$ bone $/$ fat $)=\frac{\text { Weight of meat } / \text { bone } / \text { fat }}{\text { X } 100}$

Weight of raw primal cut before dissection 
Table 2. Carcass composition of West African Dwarf ram fed garlic supplementation

\begin{tabular}{|c|c|c|c|c|c|}
\hline Items & $\begin{array}{c}\text { Treatment } 1 \\
\text { control }\end{array}$ & $\begin{array}{l}\text { Treatment } 2 \\
0.2 \% \text { garlic }\end{array}$ & $\begin{array}{l}\text { Treatment } 3 \\
0.4 \% \text { garlic }\end{array}$ & $\begin{array}{l}\text { Treatment } 4 \\
0.6 \% \text { garlic }\end{array}$ & $\begin{array}{l}\text { Treatment } 5 \\
0.8 \% \text { garlic }\end{array}$ \\
\hline $\begin{array}{l}\text { Average live } \\
\text { weight }(\mathrm{kg})\end{array}$ & $14.33 \pm 2.5^{\mathrm{a}}$ & $14.01 \pm 0.43^{\mathrm{c}}$ & $14.06 \pm 0.29^{b}$ & $13.25 \pm 0.85^{\mathrm{b}}$ & $13.72 \pm 0.39^{b}$ \\
\hline $\mathrm{HCW}(\mathrm{kg})$ & $10.8 \pm 1.61^{a}$ & $9.02 \pm 0.6^{b}$ & $10.13 \pm 0.49^{a}$ & $9.73 \pm 0.45^{b}$ & $9.99 \pm 0.77^{\mathrm{a}}$ \\
\hline $\begin{array}{l}\text { Dressing percent } \\
(\%)\end{array}$ & $54.45 \pm 1.22^{\mathrm{a}}$ & $50.58 \pm 1.87^{b}$ & $55.76 \pm 1.82^{\mathrm{a}}$ & $54.03 \pm 1.02^{\mathrm{a}}$ & $54.71 \pm 1.29^{\mathrm{a}}$ \\
\hline $\operatorname{Rib}(\%)$ & $6.02 \pm 0.74^{\mathrm{b}}$ & $7.15 \pm 0.63^{b}$ & $9.84 \pm 0.59^{\mathrm{a}}$ & $7.76 \pm 0.23^{b}$ & $9.20 \pm 0.22^{\mathrm{a}}$ \\
\hline Loin $(\%)$ & $3.18 \pm 0.39^{c}$ & $6.24 \pm 0.62^{\mathrm{b}}$ & $4.08 \pm 0.55^{\mathrm{c}}$ & $6.29 \pm 0.20^{\mathrm{b}}$ & $8.16 \pm 0.20^{\mathrm{a}}$ \\
\hline Shoulder $(\%)$ & $12.28 \pm 1.53^{\mathrm{b}}$ & $12.98 \pm 1.26^{\mathrm{b}}$ & $10.49 \pm 0.75^{\mathrm{c}}$ & $14.50 \pm 1.28^{\mathrm{a}}$ & $14.14 \pm 0.80^{\mathrm{a}}$ \\
\hline $\operatorname{Leg}(\%)$ & $12.48 \pm 1.59^{\mathrm{b}}$ & $13.47 \pm 2.24^{\mathrm{a}}$ & $12.14 \pm 0.61^{\mathrm{b}}$ & $14.81 \pm 2.27^{\mathrm{a}}$ & $12.78 \pm 0.36^{\mathrm{b}}$ \\
\hline Flank (\%) & $5.78 \pm 0.57^{b}$ & $6.23 \pm 1.30^{\mathrm{a}}$ & $5.90 \pm 0.20^{\mathrm{b}}$ & $6.60 \pm 0.75^{\mathrm{a}}$ & $6.57 \pm 0.41^{\mathrm{a}}$ \\
\hline Shank (\%) & $4.46 \pm 0.73^{b}$ & $4.46 \pm 0.73^{b}$ & $4.84 \pm 0.18^{\mathrm{b}}$ & $5.45 \pm 0.68^{a}$ & $4.79 \pm 0.16^{\mathrm{b}}$ \\
\hline Hindleg (\%) & $5.66 \pm 0.71^{b}$ & $5.53 \pm 0.77^{b}$ & $5.10 \pm 0.02^{\mathrm{b}}$ & $6.19 \pm 1.15^{\mathrm{a}}$ & $7.31 \pm 0.60^{\mathrm{a}}$ \\
\hline$*$ Head $(\%)$ & $11.68 \pm 1.41^{b}$ & $13.97 \pm 2.08^{\mathrm{a}}$ & $10.89 \pm 0.52^{\mathrm{b}}$ & $6.60 \pm 0.75^{\mathrm{c}}$ & $6.57 \pm 0.41^{\mathrm{c}}$ \\
\hline$* \operatorname{Neck}(\%)$ & $7.36 \pm 0.47^{b}$ & $8.84 \pm 0.95^{\mathrm{b}}$ & $8.08 \pm 0.43^{b}$ & $14.72 \pm 2.39^{a}$ & $15.08 \pm 2.24^{\mathrm{a}}$ \\
\hline *Tail (\%) & $0.87 \pm 0.90^{b}$ & $0.66 \pm 0.15^{c}$ & $0.50 \pm 0.02^{\mathrm{d}}$ & $1.03 \pm 0.02^{\mathrm{a}}$ & $1.01 \pm 0.05^{\mathrm{a}}$ \\
\hline
\end{tabular}

*\% traits determined relative to live weight; HCW- Hot carcass weight; a,b, c means of different superscripts on same row are significantly $(\mathrm{P}<0.05)$ different; mean \pm standard deviation

Table 3. Non-Carcass composition of West African Dwarf ram fed garlic supplementation (\%)

\begin{tabular}{lccccc}
\hline Items & $\begin{array}{c}\text { Treatment } 1 \\
\text { control }\end{array}$ & $\begin{array}{c}\text { Treatment } \\
2 \% \text { garlic }\end{array}$ & $\begin{array}{c}\text { Treatment 3 } \\
4 \% \text { garlic }\end{array}$ & $\begin{array}{c}\text { Treatment 4 } \\
6 \% \text { garlic }\end{array}$ & $\begin{array}{c}\text { Treatment 5 } \\
8 \% \text { garlic }\end{array}$ \\
\hline Lung & $1.52 \pm 0.06^{\mathrm{c}}$ & $1.95 \pm 0.01^{\mathrm{a}}$ & $1.63 \pm 0.21^{\mathrm{c}}$ & $1.44 \pm 0.04^{\mathrm{c}}$ & $1.86 \pm 0.02^{\mathrm{b}}$ \\
Liver & $1.43 \pm 0.03^{\mathrm{c}}$ & $1.98 \pm 0.01^{\mathrm{a}}$ & $1.36 \pm 0.17^{\mathrm{c}}$ & $1.34 \pm 0.02^{\mathrm{c}}$ & $1.72 \pm 0.04^{\mathrm{b}}$ \\
Heart & $0.54 \pm 0.03^{\mathrm{b}}$ & $0.63 \pm 0.02^{\mathrm{a}}$ & $0.61 \pm 0.12^{\mathrm{a}}$ & $0.55 \pm 0.03^{\mathrm{b}}$ & $0.58 \pm 0.00^{\mathrm{b}}$ \\
Kidney & $0.30 \pm 0.01^{\mathrm{b}}$ & $0.20 \pm 70.02^{\mathrm{b}}$ & $0.38 \pm 0.06^{\mathrm{a}}$ & $0.33 \pm 0.03^{\mathrm{a}}$ & $0.36 \pm 0.00^{\mathrm{a}}$ \\
Scrotum & $1.76 \pm 0.07^{\mathrm{b}}$ & $1.39 \pm 0.01^{\mathrm{c}}$ & $2.09 \pm 0.27^{\mathrm{a}}$ & $2.20 \pm 90.10^{\mathrm{a}}$ & $2.67 \pm 0.04^{\mathrm{a}}$ \\
Penis & $0.61 \pm 0.08^{\mathrm{a}}$ & $0.50 \pm 0.09^{\mathrm{b}}$ & $0.66 \pm 0.01^{\mathrm{a}}$ & $0.58 \pm 0.01^{\mathrm{b}}$ & $0.28 \pm 0.01^{\mathrm{c}}$ \\
Gall bladder & $0.05 \pm 0.01^{\mathrm{b}}$ & $0.10 \pm 0.01^{\mathrm{a}}$ & $0.12 \pm 0.00^{\mathrm{a}}$ & $0.06 \pm 0.00^{\mathrm{b}}$ & $0.09 \pm 0.01^{\mathrm{b}}$ \\
$*$ GIT & $6.64 \pm 0.85^{\mathrm{c}}$ & $9.60 \pm 0.12^{\mathrm{a}}$ & $7.81 \pm 0.18^{\mathrm{b}}$ & $10.72 \pm 3.35^{\mathrm{a}}$ & $9.83 \pm 0.58^{\mathrm{a}}$ \\
Large intestine & $2.98 \pm 0.33^{\mathrm{c}}$ & $3.40 \pm 0.43^{\mathrm{b}}$ & $3.41 \pm 0.45^{\mathrm{b}}$ & $3.39 \pm 0.30^{\mathrm{a}}$ & $3.38 \pm 0.02^{\mathrm{a}}$ \\
Small intestine & $8.95 \pm 0.21^{\mathrm{c}}$ & $9.27 \pm 0.73^{\mathrm{b}}$ & $9.96 \pm 0.05^{\mathrm{a}}$ & $9.88 \pm 0.48^{\mathrm{a}}$ & $9.28 \pm 0.15^{\mathrm{b}}$ \\
Diaphragm & $0.11 \pm 0.08^{\mathrm{c}}$ & $0.17 \pm 0.04^{\mathrm{a}}$ & $0.18 \pm 0.03^{\mathrm{a}}$ & $0.17 \pm 0.01^{\mathrm{a}}$ & $0.15 \pm 0.05^{\mathrm{b}}$ \\
Abdominal fat & $2.17 \pm 0.55^{\mathrm{a}}$ & $1.04 \pm 0.22^{\mathrm{b}}$ & $0.86 \pm 0.02^{\mathrm{b}}$ & $0.82 \pm 0.30^{\mathrm{b}}$ & $0.85 \pm 0.14^{\mathrm{b}}$ \\
\hline
\end{tabular}

*GIT: gastro intestinal tract comprises of rumen, reticulum, omasum and abomasum; a,b, c means of different superscripts on same row are significantly $(\mathrm{P}<0.05)$ different; mean \pm standard deviation 
Table 4. Percentage of dissected cuts relative to the weight of the primal cuts derived from WAD rams fed garlic powder supplemented diets $(\%)$

\begin{tabular}{|c|c|c|c|c|c|}
\hline ITEMS & $\begin{array}{l}\text { Treatment } 1 \\
\text { Control }\end{array}$ & $\begin{array}{l}\text { Treatment } 2 \\
2 \% \text { garlic }\end{array}$ & $\begin{array}{l}\text { Treatment } 3 \\
4 \% \text { garlic }\end{array}$ & $\begin{array}{l}\text { Treatment } 4 \\
6 \% \text { garlic }\end{array}$ & $\begin{array}{l}\text { Treatment } 5 \\
8 \% \text { garlic }\end{array}$ \\
\hline \multicolumn{6}{|l|}{ Loin: } \\
\hline Meat & $55.33 \pm 1.04$ & $55.70 \pm 0.61$ & $55.97 \pm 0.40$ & $56.62 \pm 0.55$ & $56.15 \pm 0.05$ \\
\hline Fat & $8.8 \pm 0.72^{\mathrm{a}}$ & $7.27 \pm 1.01^{\mathrm{ab}}$ & $6.70 \pm 0.17^{\mathrm{b}}$ & $6.05 \pm 0.35^{b}$ & $6.52 \pm 0.62^{\mathrm{b}}$ \\
\hline Bone & $35.83 \pm 0.29^{b}$ & $37.17 \pm 0.76^{\mathrm{a}}$ & $37.33 \pm 0.58^{a}$ & $37.33 \pm 0.76^{\mathrm{a}}$ & $37.33 \pm 0.58^{\mathrm{a}}$ \\
\hline Meat:Bone & $1.54: 1 \pm 0.04$ & $1.50: 1 \pm 0.04$ & $1.50: 1 \pm 0.04$ & $1.52: 1 \pm 0.05$ & $1.51: 1 \pm 0.02$ \\
\hline \multicolumn{6}{|l|}{ Rib: } \\
\hline Meat & $66.57 \pm 0.46^{\mathrm{c}}$ & $71.33 \pm 0.29^{b}$ & $72.16 \pm 0.07^{b}$ & $73.12 \pm 0.03^{\mathrm{a}}$ & $73.27 \pm 0.03^{\mathrm{a}}$ \\
\hline Fat & $10.69 \pm 0.29$ & $10.67 \pm 0.58$ & $10.58 \pm 0.08$ & $10.17 \pm 0.15$ & $10.07 \pm 0.06$ \\
\hline Bone & $22.74 \pm 0.38^{a}$ & $18.03 \pm 0.45^{b}$ & $17.26 \pm 0.11^{\mathrm{c}}$ & $16.71 \pm 0.18^{c}$ & $16.66 \pm 0.07^{\mathrm{c}}$ \\
\hline Meat:Bone & $2.93: 1 \pm 0.07^{\mathrm{d}}$ & $3.97: 1 \pm 0.11^{\mathrm{c}}$ & $4.18: 1 \pm 0.03^{b}$ & $4.38: 1 \pm 0.05^{\mathrm{a}}$ & $4.40: 1 \pm 0.02^{\mathrm{a}}$ \\
\hline \multicolumn{6}{|l|}{ Shoulder: } \\
\hline Meat & $72.23 \pm 0.25^{\mathrm{b}}$ & $72.92 \pm 0.38^{b}$ & $72.33 \pm 0.58^{b}$ & $74.33 \pm 0.58^{\mathrm{a}}$ & $74.20 \pm 0.27^{\mathrm{a}}$ \\
\hline Fat & $8.02 \pm 0.03^{\mathrm{a}}$ & $7.00 \pm 0.00^{\mathrm{b}}$ & $6.50 \pm 0.00^{\mathrm{c}}$ & $6.30 \pm 0.3^{c}$ & $5.83 \pm 0.06^{\mathrm{d}}$ \\
\hline Bone & $19.75 \pm 0.28^{\mathrm{b}}$ & $20.08 \pm 0.38^{\mathrm{a}}$ & $21.17 \pm 0.58^{a}$ & $19.53 \pm 0.64^{b}$ & $19.97 \pm 0.23^{b}$ \\
\hline Meat:Bone & $3.66: 1 \pm 0.07^{\mathrm{a}}$ & $3.63: 1 \pm 0.09^{a}$ & $3.42: 1 \pm 0.12^{b}$ & $3.81: 1 \pm 0.16^{\mathrm{a}}$ & $3.72: 1 \pm 0.06^{\mathrm{a}}$ \\
\hline \multicolumn{6}{|l|}{ Flank: } \\
\hline Meat & $89.55 \pm 0.08^{b}$ & $90.08 \pm 0.08^{b}$ & $90.83 \pm 0.58^{b}$ & $91.47 \pm 0.45^{\mathrm{a}}$ & $92.14 \pm 0.12^{\mathrm{a}}$ \\
\hline Fat & $8.21 \pm 0.06^{\mathrm{a}}$ & $7.26 \pm 0.04^{b}$ & $6.83 \pm 0.29^{c}$ & $6.21 \pm 0.18^{c}$ & $6.17 \pm 0.29^{c}$ \\
\hline Bone & $2.24 \pm 0.03^{\mathrm{a}}$ & $2.66 \pm 1.00^{\mathrm{a}}$ & $2.33 \pm 0.29^{\mathrm{a}}$ & $2.31 \pm 0.27^{\mathrm{a}}$ & $1.69 \pm 0.17^{\mathrm{b}}$ \\
\hline Meat:Bone & $39.98: 1 \pm 0.49^{b}$ & $33.94: 1 \pm 1.25^{\mathrm{c}}$ & $39.38: 1 \pm 5.51^{b}$ & $39.96: 1 \pm 1.25^{b}$ & $54.55: 1 \pm 1.87^{a}$ \\
\hline \multicolumn{6}{|l|}{ Round : } \\
\hline Meat & $90.53 \pm 0.84^{b}$ & $91.00 \pm 1.00^{b}$ & $93.23 \pm 0.40^{\mathrm{a}}$ & $94.07 \pm 0.12^{\mathrm{a}}$ & $94.17 \pm 0.76^{\mathrm{a}}$ \\
\hline Fat & $1.8 \pm 0.27^{\mathrm{b}}$ & $2.00 \pm 0.00^{\mathrm{a}}$ & $1.25 \pm 0.05^{\mathrm{c}}$ & $1.60 \pm 0.46^{\mathrm{b}}$ & $1.77 \pm 0.32^{\mathrm{b}}$ \\
\hline Bone & $7.67 \pm 0.57^{\mathrm{a}}$ & $7.00 \pm 1.00^{\mathrm{a}}$ & $5.52 \pm 0.45^{\mathrm{b}}$ & $4.33 \pm 0.35^{\mathrm{c}}$ & $4.07 \pm 0.50^{c}$ \\
\hline Meat:Bone & $11.86: 1 \pm 1.05^{\mathrm{e}}$ & $13.19: 1 \pm 2.05^{\mathrm{d}}$ & $16.98: 1 \pm 1.53^{c}$ & $29.63: 1 \pm 5.07^{a}$ & $23.41: 1 \pm 3.03^{b}$ \\
\hline
\end{tabular}

$\mathrm{a}, \mathrm{b}, \mathrm{c}, \mathrm{d}$ means of different superscripts on same row are significantly $(\mathrm{p}<0.05)$ different; mean \pm standard deviation

\subsection{Statistical analysis}

Data were analyzed by one-way analysis of variance (ANOVA) procedures for a completely randomized design experiment using the statistical software Minitab [15]. Tukey's pair wise test was used to compare mean values.

\subsection{Results}

\section{RESULTS AND DISCUSSIONS}

The average live weight of West African Dwarf rams ranged from $17.84 \pm 0.14 \mathrm{~kg}$ (treatment 2) to $19.80 \pm 2.5 \mathrm{~kg}$ (control). The mean dressing percentage ranged from $50.58 \pm 1.87 \%$ (treatment 2) to $55.76 \pm 1.82 \%$ (treatment 3). The basic statistical data showed that dressing percentage was significantly different $(\mathrm{p}<0.05)$ among treatment diets as presented in Table 2. Standard cuts derived from the half carcass were rib, loin, shoulder, leg, and flank as shown in Table 2 . Rib cut composition ranged from $6.02 \pm 0.74$ to $9.84 \pm 0.59 \%$ while loin cut ranged from $3.18 \pm 0.37$ to $8.3 \%$. The highest shoulder composition across the treatments was $14.50 \%$ while the least was $10.49 \pm 0.61 \%$. Percentage of leg cut-parts varied from $12.14 \pm 0.61$ to $14.81 \pm 2.27 \%$ and flank portion had the highest value of $6.60 \pm 0.75 \%$ in rams fed treatment 5 . There were significant differences $(\mathrm{p}<0.05)$ in the percentage weight of carcass traits. Table 3 showed that the percent non- carcass components were significantly higher $(\mathrm{p}<0.05)$ in lung, liver, scrotum, penis, gall bladder and abdominal fat of WAD rams fed treatments 2, 3, 4 and 5 than those fed treatment 1. Table 4 showed that the proportion of meat and bone of each cut-part were significantly higher $(\mathrm{p}<0.05)$ than proportion of fat among treatments. The study also revealed that the flank cut had the highest meat to bone ratio which ranged from 54.55:1 (treatment 5) to 39.38:1(treatment 3), followed by round cut ranged from 29.63:1 (treatment 4) to 11.86:1 (treatment 1). Rib cut ranged from 4.40 (treatment 5) to 2.93:1 (treatment 1) while shoulder cut ranged from 3.81:1 (treatment 4) to 3.42:1 (treatment 3). Loin cut had the least meat to bone ratio which ranged from 1.54:1(treatment 1) to $1.50: 1$ (treatments 2 and 3 ).

\subsection{Discussions}

Dressing percentage of WAD rams in this study was higher than previous reported evaluations of Kivircik and Karacabey Merino lambs [16, 17]. However, the range of dressing percentage in the current study was similar to the values ranged between 47.5 and 56.3\%) reported by others [18]. According to [13], lower cholesterol but higher weight of chilled carcass and breast meat were obtained when $2 \%$ of garlic powder was fed to broilers. However, no carcass 
change was observed when male and female Florina lambs were fed garlic bulb and husks [19].There were variations in hot carcass weight (HCW), mean live weight and hot dressing percentages (HDP) in rams fed garlic diets [20]. The live weight, slaughter weight and dressing percentage were responsible for carcass composition of animals [21,22]. Dressing percentage determines both yield and assessment of meat [23]. Garlic supplementation may have contributed immensely to quantitative traits obtained in WAD rams [24]. The percentage standard cuts showed that leg portion of the entire half carcass had the highest yield, an indication that leg portion of WAD ram can contribute immensely to meeting consumers' demand for meat, as well as increase in butchers' income [25]. The variations observed in the carcass traits revealed that high primal yield could be obtained from sheep's tissue [26]. Garlic supplementation in broiler diet increased carcass yield. Enhanced meat yield and reduced pathogen load [27].

The study of the non-carcass components revealed that abdominal fat composition decreases tremendously in garlic fed rams as the level of garlic powder inclusion increases in the diets; this might be due to fat reducing properties of garlic within the cellular components of the animals [24]. The proportions of fat and bone obtained from loin, rib, shoulder, flank and leg cuts from test diets were similar to the range values of 6.9 and $10.9 \%$ [28] and 17.1 to 20.2\% [29]. Meat to bone ratio of rib, shoulder, leg and flank cuts in this study were higher than meat to bone ratio of previous investigations $[30,16]$. This implies that the higher carcass yield observed from leg, flank, shoulder and rib cut parts in this study shows that high market value could be enhanced through garlic supplementation in animal diets [5].

\section{CONCLUSION}

The study concluded that garlic supplementation at $8 \%$ in the diets of West African Dwarf ram increased dressing percentage, carcass yield and lowered abdominal fat.

\section{ACKNOWLEDGEMENT}

The authors acknowledge the assistance of Livestock Officers of the Ruminant's unit of the Teaching and Research farm of Ekiti State University Ado-Ekiti, Ekiti State, Nigeria.

\section{REFERENCES}

1. Gbangboche, A .B., M. Adamou-Ndiaye, A.K.I.Youssao, F. Farnir, J. Detilleux, F. A. Abiola, P.I. Leroy, "Nongenetic factors affecting the reproductive performance, lamb growth and productivity indices of Djallonke sheep", Small Ruminant Research, vol.64,pp. 133-142, 2006.

2. Agaviezor, B. O., H.H. Gunn, S. A. Amusan, I.G. Imumorin, "Gene flow between Nigerian sheep breeds as revealed by microsatellite DNA markers”, J of Anim Prod 2, 35-39, 2013.

3. Fasae, O.A., B.O. Oduguwa, L. A. Adejumo, T.E. Makinde, K.A. Sanwo, "Carcass and Meat Characteristics of Traditionally Managed Nigerian Yankasa and West African Dwarf Breeds of Sheep", Pertanika J. Trop. Agric. Sci., vol. 37 no. 1, pp.101 - 108, 2014.

4. Adewumi, M.K., A. A. Jach, A.B. Omojola, "Growth performance, carcass characteristics and meat quality of WAD rams fed diets supplemented with water washed neem fruit and/or yeast", Jour of Agric, Forestry and the Social Sc. Vol.12, no.1, 2014.

5. Ocheja, J.O., J. A. Ayoade, S. Attah, J. Netala, J. Ocheni, A. Oyibo, "Carcass characteristics of growing West African Dwarf Goats fed diets containing graded levels of steam-treated Cashew Nut shell", Anim. and Vet. Sci. Special Issue: Anim. Sci. and Clim. Change, vol. 4, no. 3-1: 18-22, 2016.

6. Odusanya, L.Q., O. A. Fasae, O.O. Adewumi, I.J. James, "Effect of cassava leaf meal concentrate diets on the performance, haematology and carcass characteristics of West African Dwarf lambs", Arch. Zootec., vol. 66, no. 256,pp. 603-609, 2017.

7. Džinic, N., C. Okanoviû, M. Jokanovi, T. Tasi, V.Tomovi, P. Ikoni, S.Filipovic, "Carcass and breast meat quality of broilers feed with extruded corn. Biotechnology in animal husbandry”, vol. 27, no. 4, pp.1697-1703, 2011.

8. Andersen, H.J., N. Oksbjerg, JF.Young, M. Therkildsen, "Feeding and meat quality - a future approach", Meat Science, vol.70, pp. 543-554, 2005.

9. Al-Doobaib, S.N., H. Mousa, “ Benefits and risks of growth promoters in animal production”, J. of Food Agric and Envt. Vol. 7, pp. 202-208, 2009.

10. Valenzuela-Grijalva, N. V., A. Pinelli-Saavedra, A. Muhlia-Almazan, D. Dominguez-Diaz, H. Gonzalez-Rios, "Dietary inclusion effects of phytochemicals as growth promoters in animal production", Journal of Animal Science and Technology, vol. 59, no. 4, pp.8.1-8.17, 2017.

11. Ogbuewu, I. P., V.M. Okoro, E. F.Mbajiorgu, C. A. Mbajiorgu, "Beneficial effects of garlic in livestock: A review", Agric Res. vol. 8, no. 4, pp. 411-426, 2018.

12. Tollba, A.A.H., M.S.H. Hassan, "Using some natural additives to improve physiological and productive performance of broiler chicks under high temperature conditions. 2. Black cumin (Nigella sativa) or garlic (Allium sativum)", Poult Sci, vol. 23, pp. 327-340, 2003. 
13. Džiniû, N. , Ĉ. Okanoviû, M. Jokanoviû, V. Tomoviû, D. Paliû, “The influence of garlic powder in broiler feed on carcass and breast meat quality“, Quality of Life,vol.4,nos.3-4, pp.55-61, 2013.

14. Garcia-Valverde, R., R. Barea, L. Lara, R. Nieto, J.F. Aguilera, "The effect of feeding level upon protein and fat deposition in Iberian heavy pigs", Liv. Sci., vol.114, nos.2-3, pp. 263-273,2008.

15. Minitab, Minitab Inc. version 16.1, State College, P. A, USA, 2007.

16. Koyuncu, M.S., S. Duru S, S.U. Kara, S. Ozis, E. Tuncel, "Effect of castration on growth and carcass traits in hair goat kids under a semi intensive system in the South-Marmara region of Turkey", Small Rumin. Res., vol.72, pp.38-44, 2007.

17. Eckerman, S.E., G.P. Lardy, M. M. Thompson, B.W. Neville, M.L. Van Emon, P.T. Berg, J.S. Luther, C.S. Schauer, "Growth and Carcass Characteristics of conventionally raised Lambs versus naturally raised Lamb", Sheep and Goat Res. J., vol. 26, pp.1-7, 2011

18. Abebe, T., "Supplementation with linseed (Linum usitatissimum) cake, wheat bran and their mixtures on feed intake, digestibility, live weight changes, and carcass characteristics in intact male Arsi-Bale sheep", M.Sc. Thesis Submitted to the Department of Animal Science, School of Graduate Studies, Haramaya University, 2006.

19. Bampidis, V.A., V. Christodoulou, E. Christaki, P. Florou-Paneri, A.B. Spais, "Effect of dietary garlic bulb and garlic husk supplementation on performance and carcass characteristics of growing lambs", Animal Feed Science and Technology, vol.121, pp.273-283, 2005.

20. Yibrah, Y., I. Fletcher, W. Giza, G. Solomon, "Effect of castration on growth, fattening and market value of Black-Head Somali rams", In: IAR Proceedings of Fourth National Livestock Improvement Conference, Addis Ababa, Ethiopia, pp.133-140, 1991.

21. Mahgoub, O., I.T. Kadim, E.H. Johnson, A. Srikandakumar, N.M. Al-Saqri, A.S. Al-Abri, A. Richie, "The use of concentrate diet containing Meskit (Prosopis julifl ora) pods and date palm by-products to replace commercial concentrate diets of Omani sheep", Anim. Feed Sci. Technol., vol. 120, pp. 33-41, 2005.

22. Rahman, M.D.F., "Prediction of carcass weight from the body characteristics of Black Bengal Goats. International journal of agriculture and biology, vol. 09, no. 3, 431-434, 2007.

23. Yusuf, A.L., Y.M. Goh, A. A. Samsudin, A.R. Alimon, A.Q.Sazili, "Growth Performance, Carcass Characteristics and Meat yield of Boer goats fed diets containing leaves or whole parts of Andrographis paniculata", Asian-Australasian Journal of Animal Sciences, vol. 27, no.4, pp.503-510, 2014.

24. Karami, M., A. Alimon, Y.M. Goh, A.Q. Sazili, M. Ivan, "Effects of dietary herbal antioxidants supplemented on feedlot growth performance and Carcass composition of male Goats", American J. of Anim. and Vet. Sci., vol. 5, no.1, pp. 33-39, 2010.

25. Hatziminaouglou, J., B. Skapetas, E. Sinapis, A. Karalazos, J. Katanos, "Effect of age at slaughter on Carcass characteristics and Carcass composition in Lambs of Mountain Greek breeds". Cze. J. Anim. Sci., vol. 51, no.7, pp. 311-317, 2006.

26. van der Westhuizen, E.J., "The effect of slaughter age on the lamb characteristics of Merino, South African Mutton Merino and Dorper lambs". MSc Thesis, Stellenbosch University, US, 2010.

27. Ashayerizadeh O., B.Dastar, Shargh M.S, "Use of garlic ( Allium sativum), black cumin seeds ( Nigella sativa L.) and wild mint (Mentha longifolia) in broiler chicken diets“, Journal of Animal and Veterinary Advances, vol 8, no 9, pp.1860-1867, 2009

28. Sebsibe, A., N.H. Casey, W. A. Van Niekerk, A. Tegegne, R.J. Coertze, "Growth performance and carcass characteristics of three Ethiopian goat breeds fed grain less diets varying in concentrate to roughage ratios", S. Afr. J. of Anim. Sci., vol. 37, no. 4, pp. 221-232, 2007.

29. El-Gallad, T.T., S.M. Allam, E.A. Gihad, T.M. El-Bedawy, "Effect of energy intake and roughage ratio on the performance of Egyptian Nubian (Zaraibi) kids from weaning to one year of age", Small Rumin. Res.vol. 1, pp. 343-353, 1988.

30. Enyew, N., O.J. Rottmann, F. Pirchner, J.E.O. Rege, "Growth and carcass composition of tropical fat-tailed Menz and Horro sheep breeds”, Anim. Sci. vol.178,pp. 245-252, 2004. 